\title{
Pengembangan dan Pemberdayaan Masyarakat Desa Temukus-Besakih, Karangasem, Bali untuk Mendukung Pariwisata Berbasis Desa Wisata
}

Community Development and Empowerment of Temukus-Besakih Village, Karangasem, Bali to Support Tourism Based Tourism Village

\section{Ni Putu Diah Untari Ningsih ${ }^{1}$, Soenarto ${ }^{2}$, Sugiyono ${ }^{3}$}

\begin{abstract}
Abstrak: Pariwisata telah menjadi sektor unggulan untuk Provinsi Bali khususnya Karangasem. Kabupaten Karangasem terus berbenah diri dengan terus mengembangkan potensi wisata yang dimiliki baik potensi alam, budaya dan adat istiadatnya. Pemerintah Daerah Provinsi Bali tahun 2015-2018 melalui Program Bali Mandara Jilid II mencanangkan pembentukan 100 desa wisata salah satunya adalah Desa Temukus-Besakih. Tujuan penelitian ini adalah pengembangan dan pemberdayaan masyarakat Desa Temukus-Besakih untuk mendukung pariwisata berbasis desa wisata. Metode yang digunakan dalam penelitian ini adalah interpretatif naturalistik, dengan langkah-langkah sebagai berikut: grand tours, observasi, survei, dan studi literatur dengan meninjau literatur yang berhubungan dengan topik penelitian. Hasil penelitian menunjukkan potensi yang dimiliki Desa Temukus-Besakih dalam mewujudkan desa wisata dilihat dari kriteria desa wisata antara lain: atraksi, jarak tempuh, sistem kepercayaan, dan ketersediaan infrastruktur. Konsep dasar pengembangan Desa Temukus-Besakih sebagai desa wisata adalah Desa Wisata Berkelanjutan. Konsep pengembangan dari konsep dasar tersebut terdiri dari rencana tata ruang yaitu, zona lingkungan, zona sosial budaya, dan zona ekonomi.
\end{abstract}

Kata kunci: Desa Wisata, Temukus-Besakih, Pariwisata, Karangasem

Abstract: Tourism has become a leading sector for Bali Province, especially Karangasem. Karangasem Regency continues to improve itself by continuing to develop tourism potential that has both the potential of nature, culture and customs. Bali Provincial Government in 2015-2018 through the Bali Mandara Volume II Program launched the establishment of 100 tourism villages, one of which was Temukus-Besakih Village. The purpose of this study is to develop and empower the people of Temukus-Besakih Village to support village-based tourism. The method used in this study is interpretative naturalistic, with the following steps: grand tours, observations, surveys, and literature studies with literature relating to the topic of research. The results showed the potential possessed by Temukus-Besakih Village in realizing tourism villages seen from the criteria of tourist villages, among others: attractions, distance traveled, religion, and infrastructure availability. The basic concept of developing Temukus-Besakih Village as a tourism village is

\footnotetext{
${ }^{1}$ Pendidikan Agama Hindu, Ilmu Pendidikan, STKIP Agama Hindu Amlapura

2 Pendidikan Teknologi dan Kejuruan, Pascasarjana, Universitas Negeri Yogyakarta

${ }^{3}$ Manajemen Pendidikan, Pascasarjana, Universitas Negeri Yogyakarta
} 
Sustainable Tourism Village. The concept of development of the basic concept consists of spatial plans namely environmental zones, socio-cultural zones, and economic zones.

Keywords: tourism village, temukus-besakih, tourism, Karangasem

\section{PENDAHULUAN}

Pariwisata telah menjadi sektor unggulan bagi perekonomian Indonesia. Perkembangan pariwisata dari tahun ke tahun sangat memberi dampak yang signifikan terhadap pertumbuhan perekonomian Indonesia, Bali salah satunya. Bali merupakan icon pariwisata Indonesia yang telah diakui dunia. Ketika mendengar nama Bali maka hal pertama yang terlintas di pikiran kita adalah destinasi wisata yang ada di dalamnya baik itu alam, pura, budaya dan tradisi unik yang di lakukan secara turun-temurun oleh masyarakat Bali. Jumlah wisatawan mancanegara ke Provinsi Bali pada bulan Juni 2018 naik sebesar 3,03 persen (544.550 kunjungan) dibandingkan pada bulan Mei 2018 sebesar 528.512 kunjungan ("Badan Pusat Statistik Kabupaten Karangasem," 2018). Walaupun demikian secara struktur ekonomi, Kabupaten Karangasem masih tertinggal dibandingkan dengan daerah-daerah lain di Propinsi Bali. Sektor industri pariwisata yang menjadi basis ekonomi ternyata tidak memberikan dampak yang cukup signifikan terhadap sumber pendapatan ekonomi wilayah maupun kesejahteraan masyarakat Kabupaten Karangasem secara umum.

Pendapatan asli daerah Kabupaten Karangasem berada dalam kelompok pendapatan asli daerah yang kecil. Tahun 2017 pendapatan asli daerah Kabupaten Karangasem sebesar Rp 198.575.057 juta, jumlah ini menurun dibandingkan pada tahun 2016 yang berjumlah Rp 318.083.799 juta ("Badan Pusat Statistik Provinsi Bali," 2017). Hal ini disebabkan oleh menurunnya jumlah pajak daerah yang diterima oleh pemerintah Kabupaten Karangasem. Penurunan pajak daerah ini bisa dikarenakan berbagai sumber salah satunya dari penerimaan dari pajak hotel dan restoran yang kurang maksimal. Hal ini dikarenakan banyak hotel, villa, dan restoran yang menunggak pajak (Istri \& Permata, 2016).

Berdasarkan data-data tersebut, Kabupaten Karangasem dinyatakan sebagai salah satu kabupaten di Provinsi Bali yang dikenal sebagai daerah yang tertinggal. Namun Kabupaten Karangasem terus berbenah diri dengan meningkatkan pembangunannya di berbagai sektor salah satunya dari sektor pariwisata. Pemerintah Kabupaten Karangasem terus menggali dan mengembangkan potensi wisata yang dimiliki baik potensi alam maaupun budaya dan adat istiadatnya. Oleh sebab itu perlu adanya inovasi dalam sektor pariwisata.

Dalam satu dekade terakhir, perkembangan tren perjalanan wisatawan ditandai dengan munculnya motivasi dan pola perjalanan wisata baru yang dilakukan oleh wisatawan, khususnya pada segmen pasar wisatawan yang sudah berpengalaman (mature market), dan yang berpendidikan serta memiliki tingkat kepedulian yang tinggi terhadap isu-isu terkini seperti konservasi lingkungan, pariwisata berkelanjutan, pariwisata berbasis masyarakat, serta budaya lokal. Perubahan yang dimaksud adalah terjadinya kecenderungan pola perjalanan dari wisata massal (mass tourism) ke arah wisata alternatif (alternative tourism). Wisata alternatif merupakan bentuk penyeimbang terhadap perkembangan wisata massal yang begitu pesat dan dipandang kurang ramah terhadap lingkungan serta kurang berpihak kepada komunitas lokal. Perubahan pola perjalanan wisatawan tersebut berkembang lebih luas pada beragam jenis kegiatan wisata yang berorientasi pada pengenalan terhadap alam atau budaya lokal dengan motivasi untuk pengayaan wawasan, pengembangan diri serta aktualisasi diri, dengan bentuk-bentuk wisata petualangan seperti hiking, trekking, wisata minat khusus (bird watching, wild life viewing), wisata budaya dan desa wisata (tourism village) (Prasiasa, 2017). 
Desa wisata secara internasional dikenal dengan berbagai istilahnya seperti village tourism, rural tourism, farm tourism, atau agro tourism telah banyak dilaksanakan di berbagai negara, seperti di Swiss, Kenya, Senegal, Yunani, Jerman, dan Muangthai (Dowling, 2003; Garcia-Ramon, Canoves, \& Valdovinos, 1995; Iakovidou \& Turner, 1995; Leu, 1992; Naisbitt, 1995; Oppermann, 1996). Upaya pengembangan wisata alternatif berupa desa wisata yang sesuai dengan karateristik desa merupakan langkah tepat dalam mengantisipasi kejenuhan terhadap produk-produk wisata yang sudah ada. Pengembangan desa wisata juga dapat memberikan sejumlah peluang bagi pemberdayaan potensi-potensi daya tarik wisata yang ada di desa dengan keunikannya untuk dapat dikemas dan dikembangkan sekaligus dapat meningkatkan keberdayaan masyarakat desa melalui kegiatan ekonomi pariwisata yang tumbuh dan berkembang.

Pemerintah Daerah Provinsi Bali tahun 2015-2018 melalui Program Bali Mandara Jilid II mencanangkan pembentukan 100 desa wisata yang tersebar pada 8 kabupaten dan 1 kotamadya. Seratus desa wisata tersebut penyebarannya masing-masing 22 desa wisata di Kabupaten Buleleng, 6 desa wisata di Kabupaten Jembrana, 16 desa wisata di Kabupaten Tabanan, 5 desa wisata di Kabupaten Badung, 15 desa wisata di Kabupaten Gianyar, 10 desa wisata di Kabupaten Klungkung, 11 desa wisata di Kabupaten Bangli, 10 desa wisata di Kabupaten Karangasem, dan 5 desa wisata di Kotamadya Denpasar. Desa Wisata Temukus-Besakih adalah salah satu dari 10 desa wisata yang dikembangkan di Kabupaten Karangasem melalui Program Bali Mandara Jilid II, sedangkan sembilan lainnya adalah desa wisata Budekeling, Sibetan, Tenganan, Prangsari, Iseh, Antiga, Jasri, Timbrah, dan Munti Gunung (METROBALI, 2013).

Sejak ditetapkan sebagai desa wisata, dalam operasionalnya Desa Wisata TemukusBesakih belum menunjukkan hasil yang sesuai dengan harapan pengembangan desa tersebut sebagai desa wisata, baik dari segi kelembagaan (ancilarry), kerjasama dengan stakeholders pariwisata, maupun pemberdayaan masyarakat dalam operasional desa wisata. Berdasarkan uraian tersebut, maka rumusan masalah penelitian ini adalah sebagai berikut. (1) Strategi apa sajakah yang dapat diterapkan dalam mendukung pengembangan Desa Temukus-Besakih sebagai desa wisata?. (2) Bentuk-bentuk pemberdayaan apa saja yang dapat dilakukan untuk mendukung pengembangan Desa Temukus-Besakih sebagai desa wisata?

\section{METODE}

Penelitian ini berlokasi di Desa Temukus-Besakih, Kecamatan Rendang, Kabupaten Karangasem, Provinsi Bali. Desa Temukus memiliki letak geografis yang strategis karena mudah diakses dari kota Denpasar kurang lebih selama 1 Jam 39 Menit melalui J1. Prof. Dr. Ida Bagus Mantra dengan menggunakan mobil. Metode yang digunakan dalam penelitian ini adalah interpretatif naturalistik, dengan langkah-langkah sebagai berikut: Grand tours, observasi, survei, dan studi literatur dengan meninjau literatur yang berhubungan dengan topik penelitian. Teori dan ide yang terkandung dalam sumber pustaka digunakan sebagai dasar bagi peneliti untuk mendeskripsikan, menganalisa dan memunculkan ide-ide baru untuk menjawab topik seputar Pengembangan dan Pemberdayaan Masyarakat Desa Temukus, Karangasem, Bali untuk Mendukung Pariwisata Berbasis Desa Wisata.

Teknik analisis data yang digunakan dalam penelitian ini adalah analisis SWOT (Strenght, Weakness, Opportunity, and Threat). Teknik SWOT digunakan untuk menganalisis dan mengklasifikasikan secara kuantitatif faktor internal dan eksternal yang mempengaruhi bisnis suatu organisasi, menganalisis faktor pendorong, memetakannya, dan mendefinisikan strategi berdasarkan pemetaan tersebut, melihat berbagai alternatif kebijakan yang mungkin dilakukan. Analisis ini didasarkan pada logika yang dapat memaksimalkan kekuatan (Strengths) dan peluang (Opportunities), namun secara bersamaan dapat meminimalkan kelemahan (Weaknesses) dan ancaman (Threats) (Rangkuti, 2017). 


\section{HASIL DAN PEMBAHASAN}

\section{Kondisi Umum Desa Temukus-Besakih}

Desa Temukus merupakan bagian dari desa Besakih yang berada di Bali Timur, Kecamatan Rendang, Karangasem yang berdekatan dengan pura paling suci yaitu Pura Besakih di Bali. Menurut data dari website resmi Besakih (2018), Desa Temukus-Besakih memiliki luas wilayah $21,23 \mathrm{Ha}$, bila ditinjau dari segi geografisnya terletak antara BT 115 8 - $36 \mathrm{MN}$ dan LS $708-24 \mathrm{ME}$ dengan ketinggian antara 750/1100 m dari permukaan laut, dan ketinggian antara $10-25$ mengarah ke utara.

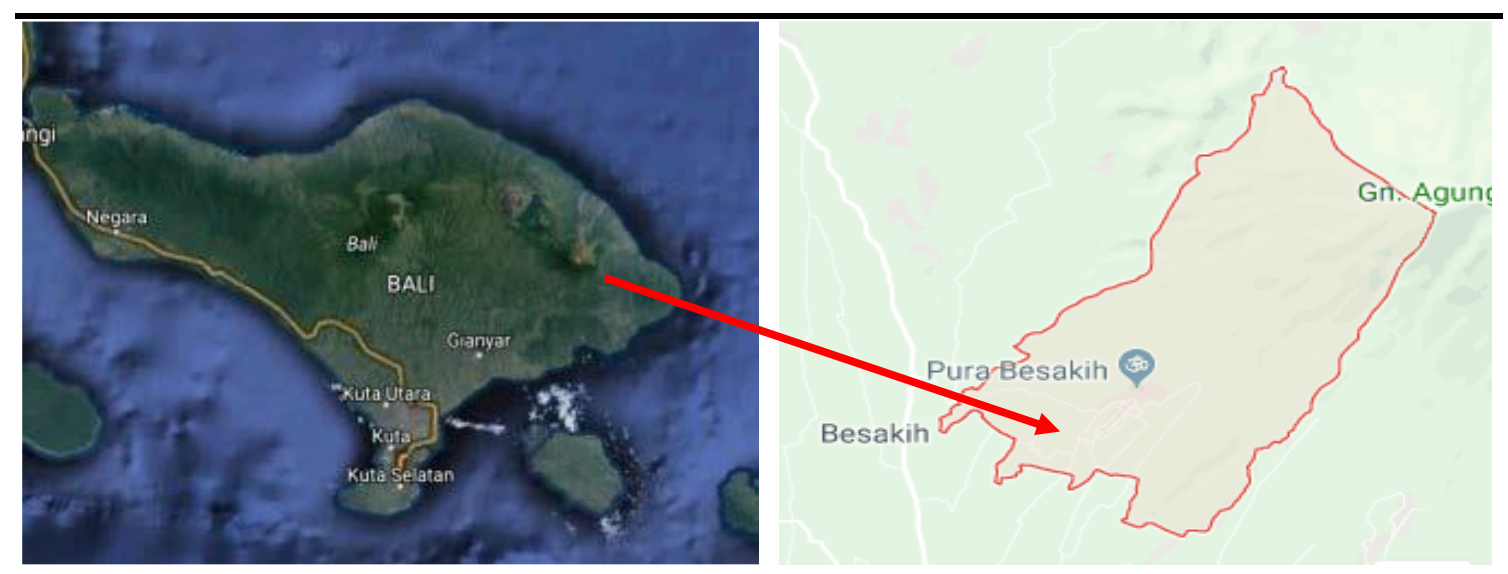

Sumber: Besakih - Google Maps, 2018)

\section{Gambar 1. Peta Lokasi Desa Temukus-Besakih}

Iklim di Desa Temukus-Besakih adalah Sub Tropis dengan curah hujan rata-rata 2000-3000 mm/tahun, dengan temperature berkisar antara $25 \mathrm{C}-37$ C. Keadaan topografi Desa Besakih beraneka ragam dan merupakan wilayah dinamis terdiri dari: daerah dataran, perbukitan hingga daerah pegunungan. Dari lahan bukan sawah seluas $2.123 \mathrm{Ha}$, terdiri dari lahan kering seluas $2.123 \mathrm{Ha}(100 \%)$. Lahan kering terdiri dari kebun/tegalan seluas $790 \mathrm{Ha}(37,22 \%)$,kawasan hutan rakyat seluas $1.271 \mathrm{Ha}(59,86$ \%),lahan kering lainnya, pekarangan seluas $47 \mathrm{Ha}(2,22 \%)$ lain-lain $15 \mathrm{Ha}(0,70 \%)$. Pola penggunaan lahan sangat dipengaruhi oleh pertumbuhan penduduk dan perkembangan perekonomian desa sehingga cenderung mengalami perubahan pemanfaatan lahan setiap tahunnya sebagai akibat alih fungsi lahan terutama dari lahan pertanian ke non pertanian seperti misalnya pengembangan pemukiman, pariwisata dan pembangunan lainnya.

Desa Besakih terdiri dari 11 Banjar Dinas/Adat, 5 Desa Adat. Untuk menjalankan roda pemerintahan di masing masing tingkat wilayah dikepalai oleh seorang Kelihan Dinas untuk tingkat Banjar Dinas, Bendesa Adat untuk tingkat Desa Adat/Pakraman. Batasbatas wilayah Desa Besakih adalah: (a) Sebelah utara: Gunung Agung, (b) Sebelah Timur: Kecamatan Selat, (c) Sebelah Selatan: Desa Menanga, dan (d) Sebelah Barat: Desa Pempatan. Adapun luas masing-masing wilayah Banjar Dinas disajikan pada tabel 2 berikut ini.

Tabel 1. Luas Wilayah Desa Besakih Per Dusun/Banjar Tahun 2015

\begin{tabular}{|c|c|c|c|}
\hline \multirow{2}{*}{ Banjar Dinas } & \multicolumn{2}{|c|}{ Luas Wilayah } & \multirow{2}{*}{$\begin{array}{c}\text { Jumlah Penduduk } \\
\text { (Jiwa) }\end{array}$} \\
\hline & $\mathrm{Ha}$ & Persentase & \\
\hline Angsoka & 198 & 9,32 & 595 \\
\hline Batang & 219 & 10,31 & 657 \\
\hline Batumadeg & 169 & 7,96 & 473 \\
\hline Besakih Kangin & 124 & 5,84 & 650 \\
\hline Besakih Kawan & 358 & 16,86 & 920 \\
\hline
\end{tabular}




\begin{tabular}{lccc}
\hline \multirow{2}{*}{ Banjar Dinas } & \multicolumn{2}{c}{ Luas Wilayah } & Jumlah Penduduk \\
\cline { 2 - 3 } & Ha & Persentase & (Jiwa) \\
\hline Kesimpar & 78 & 3,67 & 556 \\
Kedungdung & 91 & 4,28 & 511 \\
Kidulingkerteg & 115 & 5,41 & 370 \\
Kunyit & 342 & 16,10 & 1218 \\
Palak & 68 & 3,20 & 353 \\
Temukus & 361 & 17,00 & 839 \\
\hline
\end{tabular}

Sumber: Desa Besakih, 2017

\section{Potensi dan Permasalahan}

Banyak warga desa tersebut yang menanam bunga. Terdapat dua taman bunga yang saat ini berada di desa tersebut, yaitu Padang Bunga Kasna dan Taman Gemitir (Marigold). Bunga Kasna merupakan pelengkap sarana sembahyang umat Hindu di Bali, sama halnya dengan bunga Kasna, Bunga Gemitir (Marigold) juga merupakan unsur pokok yang ada pada canang (sarana persembahyangan Umat Hindu di Bali). Penduduk Pulau Bali yang mayoritas adalah memeluk Agama Hindu tidak bisa lepas dari ritual keagamaan yang memerlukan perlengkapan sembahyang dari bunga, sehingga banyak penduduk Desa Temukus bekerja sebagai petani bunga. Taman-taman yang ada di Desa Temukus adalah lahan milik pribadi yang dikelola sendiri oleh warga setempat.

Selain itu sektor pertanian merupakan sektor yang sangat penting peranannya dalam menumbuh kembangkan perekonomian desa, hal ini disebabkan karena sebagian besar masyarakat berusaha di sektor pertanian. Beberapa komoditas yang dominan diusahakan adalah tanaman pangan yaitu palawija dan holtikultura, perkebunan yaitu kopi dan cengkeh serta peternakan yaitu sapi, babi, ayam, dan kambing. Dalam 5 tahun kedepan pembangunan sektor pertanian diarahkan untuk lebih meningkatkan produktifitasnya dalam rangka meningkatkan laju pertumbuhan ekonomi dan peningkatan pendapatan masyarakat desa, oleh karena itu reorientasi pembangunan pertanian kearah agribisnis merupakan hal utama yang harus mendapat perhatian ("Desa Besakih," 2017)

Pemberdayaan koperasi dan UMKM merupakan salah satu upaya strategis dalam meningkatkan perekonomian masyarakat desa. Upaya pengembangan koperasi dan UMKM diarahkan untuk meningkatkan kemampuan para pelaku ekonomi, sehingga mempunyai daya saing yang handal. Pada saat ini Desa Besakih memiliki 8 buah koperasi.

Tabel 2. Koperasi Desa Besakih Per Dusun/Banjar Tahun 2015

\begin{tabular}{ll} 
Nama Koperasi & Alamat \\
\hline Koperasi Samba Mandiri & Banjar Dinas Kunyit \\
Koperasi Basuki Merta Sedana & Banjar Dinas Kunyit \\
Koperasi Sila Dana Kembang & Banjar Dinas Temukus \\
Koperasi Giri Sari Arta (GSA) & Banjar Dinas Besakih kangin \\
Koperasi Wana Sari & Banjar Dinas Besakih kangin \\
Koperasi Sila Mukti & Banjar Dinas Batumadeg \\
Koperasi Merta Sedana & Banjar Dinas Kedungdung \\
Koperasi Tapa Sari & Banjar Dinas Kedungdung \\
\hline
\end{tabular}

Sumber: Desa Besakih, 2017

Tidak hanya itu, pembangunan bidang pariwisata tetap mengedepankan daya tarik wisata (DTW) lingkungan yang menitik beratkan pada nilai-nilai budaya dan kearifan local sehingga manfaat pariwisata tidak terlalu banyak berdampak negative. Pengelolaan pariwisata difokuskan pada penataan kawasan secara intensif dan komperhensif. Sedangkan potensi perdagangan di Desa Besakih mempunyai prospek yang cukup luas karena sebagai salah satu destinasi pariwisata dunia, maka sektor perdagangan memiliki peluang yang sangat besar untuk dikembangkan. Pengembangan sektor industri masih terbatas pada skala kecil untuk kebutuhan lokal dan beberapa produk yang secara khusus untuk kebutuhan pariwisata. 
Tabel 3. Jenis Industri Desa Besakih per Dusun/Banjar Tahun 2015

\begin{tabular}{ll}
\hline Jenis Industri & Alamat \\
\hline Kerajinan Besek & Banjar Dinas Batang \\
Kerajinan Pande Besi & Banjar Dinas Batang \\
Kerajinan Pande Besi & Banjar Dinas Palak \\
Kerajinan Keranjang & Banjar Dinas Kunyit \\
Kerajinan Ukir Kayu & Banjar Dinas Kunyit \\
Kerajinan Sanggah & Banjar Dinas Batang, Kedungdung, Besakih Kangin, \\
& Palak \\
Kerajinan Sangkar Burung/Ayam & Banjar Dinas Kunyit \\
\hline
\end{tabular}

Sumber: Desa Besakih," 2017

\section{Analisis SWOT Desa Wisata Temukus-Besakih}

Pengembangan daya tarik wisata di Desa Temukus-Besakih, Kabupaten Karangasem, telah diidentifikasi faktor internal (Kekuatan dan Kelemahan) dan eksternal (Peluang dan Ancaman) pengembangan wisata desa sebagai berikut:

a. Kekuatan (S), Desa Temukus-Besakih memiliki potensi untuk dikembangkan menjadi produk wisata berbasis budaya, Desa Temukus-Besakih ditetapkan sebagai Desa Wisata sejak tahun 2015, melalui Program Bali Mandara Jilid II. Desa TemukusBesakih memiliki masyarakat setempat sangat terbuka terhadap adanya pengembangan pariwisata, Desa Temukus-Besakih merupakan desa dengan tingkat keamanan yang baik, Desa Temukus-Besakih memiliki awig-awig (aturan adat) yang mendukung pengembangan desa wisata, dan tersedia penunjuk arah ke lokasi daya tarik wisata.

b. Kelemahan (W), Belum memiliki sumber daya manusia yang kompeten dan professional di bidang pariwisata, tidak semua aktifitas budaya dapat dikomersialisasikan/dijual untuk kebutuhan pariwisata, keterbatasan dana untuk pengembangan fasilitas wisata dan pelatihan sumber daya manusia, belum memiliki sistem pengelolaan pariwisata yang terencana dan sistematis, belum memiliki regulasi resmi yang mengatur kepariwisataan desa, belum memiliki sistem pengelolaan sampah plastik, belum memiliki standar higienis untuk layanan makan dan minum, jaringan komunikasi (internet) masih terbatas untuk beberapa provider, belum tersedia media yang dapat mendukung interpretasi wisatawan terhadap daya tarik wisata di Desa Temukus-Besakih (brosur, information center, guide), jumlah kunjungan wisatawan masih sedikit, dan belum ada paket wisata dari biro perjalanan/travel agent yang menawarkan aktifitas di Desa Temukus-Besakih.

c. Peluang (O), visi dan misi Disbudpar Kabupaten Karangasem, mendukung perkembangan produk wisata berbasis desa wisata, pelestarian lingkungan fisik dan budaya sebagai dampak positif pengembangan pariwisata, peningkatan jumlah pendapatan dan ketersediaan lapangan pekerjaan, kemajuan teknologi informasi dan komunikasi.

d. Ancaman (T), perubahan lingkungan fisik (pencemaran, limbah, sampah, dan polusi), bencana alam (gempa bumi, gunung meletus, banjir, tanah longsor), muncul destinasi (desa wisata) lain yang menawarkan produk serupa, terjadinya eksploitasi budaya secara berlebihan, sehingga tidak ada batasan antara aktifitas sakral dan seni pertunjukan, dan masyarakat dapat dengan mudah terpengaruh oleh budaya asing yang tidak sesuai dengan norma/adat setempat.

\section{Konsep Pengembangan}

Berdasarkan hasil analisis SWOT, akan ditentukan program-program yang sesuai untuk pengembangan dan pemberdayaan masyarakat Desa Temukus-Besakih untuk mendukung pariwisata berbasis desa wisata. Konsep dasar yang digunakan dalam perencanaan ini adalah konsep "Desa Wisata Berkelanjutan". Berdasarkan perkembangan tren perjalanan wisatawan dan juga kecenderungan pola perjalanan dari wisata massal 
(mass tourism) ke arah wisata alternatif (alternative tourism) maka berkembang menjadi desa wisata atau yang lebih dikenal secara internasional dengan istilah village tourism. Perbedaan desa wisata village tourism, rural tourism, farm tourism, atau agro tourism yang telah banyak dilaksanakan di berbagai negara, seperti di Swiss, Kenya, Senegal, Yunani, Jerman, dan Muangthai adalah di konsep dasar perencanaan desa wisata tersebut dimana masingmasing daerah atau desa memiliki keunikan dan potensi yang bisa dioptimalkan sesuai dengan kondisi dari daerah atau desa tersebut.

Dalam konsep dasar perencanaan ini dilakukan dengan pendekatan sumber daya, dengan menentukan tipe-tipe alternatif aktivitas rekreasi dan wisata berdasarkan pertimbangan kondisi serta situasi sumber daya, sehingga menciptakan kawasan desa wisata berkelanjutan, yang bisa menjamin keberlangsungan atau keberadaan sumber daya alam dan kehidupan sosial-budaya serta memberikan manfaat ekonomi bagi masyarakat setempat hingga generasi yang akan datang. Arti berkelanjutan adalah kawasan desa wisata yang tidak mencemari atau merusak lingkungan, menguntungkan secara ekonomi, dan dapat diterima oleh masyarakat (Subrata \& Nyoman Mastiani Nadra, 2006). Konsep tata ruang yang direncanakan disesuaikan dengan potensi tapak dengan memperhatikan aspek lingkungan, aspek sosial budaya dan aspek ekonomi. Pembagian ruang pada tapak di bagi dalam tiga zona yaitu zona lingkungan, zona sosial budaya, dan zona ekonomi (Putra, Wayan, Utam, Agung, \& Sugianthara, 2017).

\section{Strategi Pengembangan dan Pemberdayaan Masyarakat}

Pengembangan zona lingkungan meliputi area pertanian/perkebunan dan tempat pengelolaan limbah di Desa Temukus-Besakih. Area pengelolaan limbah berfungsi untuk penampungan limbah padat maupun cair yang organik, anorganik dan B3 (Bahan beracun dan berbahaya). Tata hijau yang diterapkan yaitu: fungsi ekologis, fungsi sosial budaya dan fungsi ekonomi. Tanaman yang digunakan yaitu tanaman hortikultura sayur, buah dan obat-obatan. Area pertanian terutama pertanian bunga kasna dan gemitir (marigold) yang dikelola oleh warga setempat, dan dijadikan objek wisata oleh wisatawan yang dating ke desa Temukus-Besakih. Kebun Bunga Gemitir memiliki makna yang sangat penting bagi masyarakat Bali. Bunga Gumitir adalah salah satu bunga yang menjadi pilihan utama masyarakat Bali untuk membuat persembahan atau sesajen. Bunga ini juga banyak digunakan oleh pelaku pariwisata di Pulau Dewata baik berupa bunga potong maupun pot sebagai penghias ruangan dan taman. Permintaan bunga yang memiliki nama ilmiah Tagetes Erecta ini di Bali sangat tinggi dan akan meningkat bersamaan dengan pelaksanaan upacara hari besar keagamaan.

Sejalan dengan kebun bunga gemitir, kebun bunga kasna juga tidak kalah menarik. Bunga Kasna memiliki warna putih yang biasanya warga sekitar menyebutnya dengan Bunga Kasna, awal mula tumbuhan ini hidup liar di sela bebatuan puncak Gunung Agung, lama kelamaan di tanam dan di budidayakan oleh warga di lahan sekitar rumah mereka yang nantinya dijual untuk bahan pelengkap sarana persembahyangan Umat Hindu. Tak heran juga tumbuhan ini tumbuh subur di Desa Temukus, hal ini dipengaruhi oleh iklim dan suhu yang dingin, karena letaknya di dataran tinggi dan dekat dengan Gunung Agung. Bunga Kasna sendiri memang sementara ini hanya bisa hidup di desa Temukus Karangasem, tidak bias ditemukan di tempat lainnya, sehingga ini menjadi daya Tarik wisata tersendiri. Padang Bunga Kasna di desa Temukus ini diperkenalkan secara tidak sengaja oleh seorang pendaki Gunung Agung yang kebetulan singgah dan mampir ke desa ini, terpesona dengan keindahan alam yang disuguhkan, kemudian pendaki gunung tersebut mengambil hamparan bunga tersebut dan diunggah di internet. Padang Bunga Kasna dan Padang Bunga Gemitir memang sebuah tempat instagramable di Bali dan khusunya di Karangasem. 


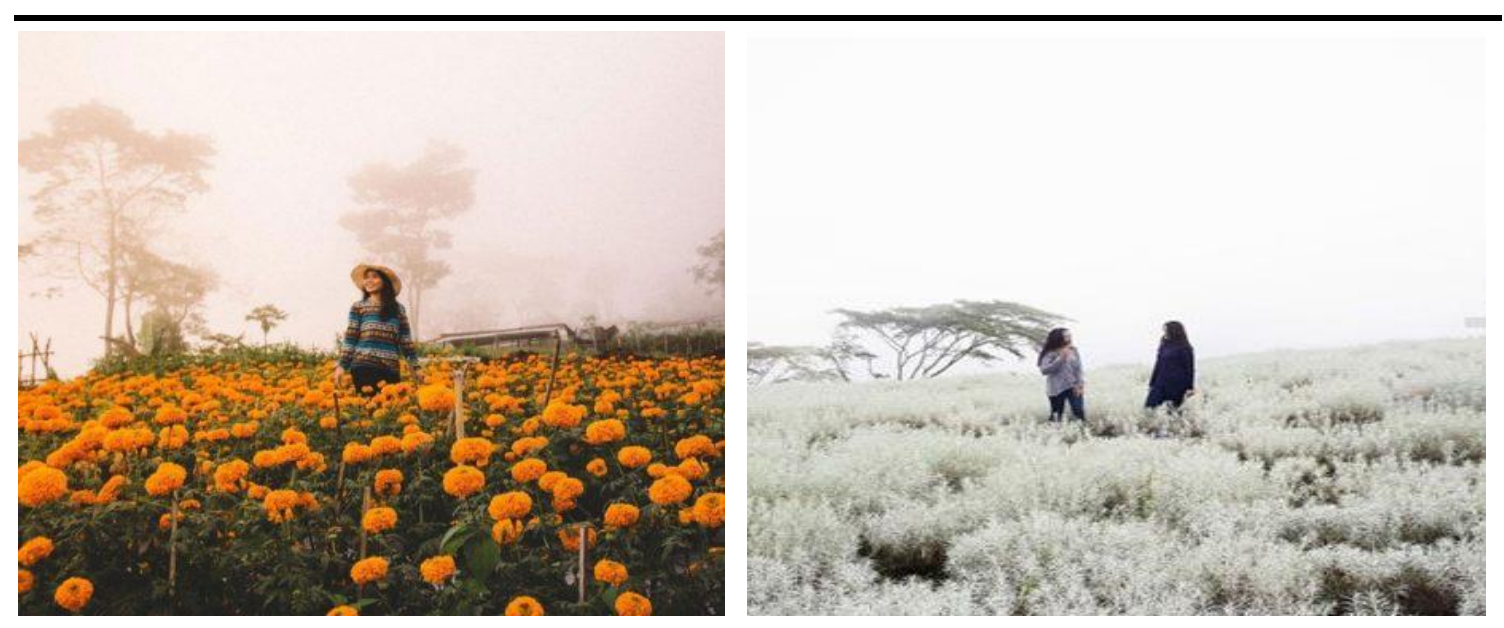

Sumber: (Fenty, 2017)

\section{Gambar 2. Padang Bunga Gemitir (kiri) dan Padang Bunga Kasna (Kanan)}

Pengembangan zona sosial budaya meliputi kawasan pura, pemukiman dan area pemakaman penduduk Desa Temukus-Besakih. Pada zona budaya pengunjung dapat melakukan berbagai aktifitas antara lain: menyaksikan berbagai pelaksanaan tradisi dan budaya yang ada di desa Temukus seperti Usaba Kaulu, Usaba Kedasa, Tari Rejang, Usaba Sumbhu dan berbagai upacara agama atau tradisi lainnya yang ada di Desa Temukus-Besakih serta wisatawan dapat mengabadikan momen pelaksanaan tradisi tersebut, selain itu pengunjung dapat mempelajari cara pembuatan sarana upakara, belajar tari Bali, belajar membuat jajanan Bali, dan belajar memainkan gamelan. Fasilitas pendukung yang ada pada zona budaya antara lain: wantilan, pura, akses jalan, rumah warga, pusat informasi, papan informasi, pedestrian, tempat parkir, tempat sampah, toilet umum, dan lampu penerangan jalan.

Tabel 4. Bentuk-bentuk Pemberdayaan Masyarakat yang Dapat Dilakukan terhadap Masyarakat di Desa Wisata Temukus-Besakih

\begin{tabular}{ll}
\hline Aktivitas/Daya Tarik & Bentuk Pemberdayaan Masyarakat \\
\hline Membuat kerajinan lokal & $\begin{array}{l}\text { Menyiapkan an alat, menyiapkan bahan, } \\
\text { mendemonstrasikan proses pembuatan kerajinan local } \\
\text { khas Desa Temukus-Besakih }\end{array}$ \\
Pengamanan & $\begin{array}{l}\text { Sebagai sekuriti atau pecalang pada daya tarik wisata di } \\
\text { Desa Temukus-Besakih } \\
\text { Mejejahitan }\end{array}$ \\
& $\begin{array}{l}\text { Menyiapkan alat seperti pisau (lemat), dan bahan (janur, } \\
\text { daun rontal, semat, dll), mendemonstrasikan proses }\end{array}$ \\
& pembuatan jejahitan kepada wisatawan \\
Menabuh & Menyiapkan gamelan serta melatih wisatawan \\
& memainkan gamelan tradisional \\
Menari & Menyiapkan gamelan/musik pengiring tarian, melatih \\
& wisatawan menari \\
Upacara keagamaan & Memberikan informasi terkait upacara keagamaan yang \\
& unik di Desa Temukus-Besakih sekaligus menjadi \\
pemandu wisata lokal & Memandu Wisatawan (biasanya berwisata ke padang \\
Pemandu Wisata & bunga dan Pura Besakih)
\end{tabular}

Sumber: Peneliti, 2018

Pengembangan zona ekonomi merupakan zona yang dapat memberikan dampak ekonomi bagi masyarakat Desa Temukus-Besakih yang meliputi area pertanian, perkebunan, dan peternakan. Terutama pada area pertanian/perkebunan bunga yang telah 
mengangkat ekonomi warga. Mengenai nilai jual bunga Gumitir menurut Kepala Dinas Pertanian Tabanan, Nyoman Budana, tergantung dari permintaan pasar. Saat permintaan tinggi terutama saat banyak upacara keagamaan, harga bunga ini bisa mencapai Rp 40.000 per kilogram. Namun saat permintaan rendah dan produksi banyak harga jualnya hanya Rp 5000 per kilogramnya. Tetapi rata-rata bunga ini dibeli di petani sekitar Rp 15.000 per kilogram (BALIPOST, 2017).

Selain produksi bunga, Desa Temukus-Besakih juga memiliki kerajinan yang dapat dijual, seperti: kerajinan besek, kerajinan keranjang, kerajinan ukir kayu, kerajinan sanggah, dan kerajinan sangkar burung/ayam. Ditambah dengan adanya Pemberdayaan koperasi dan UMKM merupakan salah satu upaya strategis dalam meningkatkan perekonomian masyarakat desa. Upaya pengembangan koperasi dan UMKM diarahkan untuk meningkatkan kemampuan para pelaku ekonomi, sehingga mempunyai daya saing yang handal. Sehingga harapannya dengan adanya desa wisata Temukus-Besakih, pendapatan asli daerah Kabupaten Karangasem untuk tahun kedepannya mengalami peningkatan lebih baik dari tahun 2017 dan Kabupaten Karangasem secara struktur ekonomi, tidak dianggap menjadi Kabupaten yang tertinggal lagi di Provinsi Bali. Sektor industri pariwisata di Karangasem dengan adanya desa wisata Temukus-Besakih diharapkan menjadi basis ekonomi untuk Kabupaten Karangasem khususnya dan Provinsi Bali pada umumnya.

\section{KESIMPULAN}

Potensi yang dimiliki Desa Temukus-Besakih dalam mewujudkan desa wisata dilihat dari kriteria desa wisata antara lain: a) atraksi berupa: pantai, sawah, perkebunan, Bukit Apen, Usaba Kasa, Tari Rejang Desa, Usaba Kaulu, Meami-amianan dan Usaba Sumbu, b) Jarak tempuh yaitu: dekat dengan Kota Amlapura, Obyek Wisata Candidasa, Taman Soekasada Ujung dan Taman Tirta Gangga, c) Besaran desa antara lain: jumlah rumah penduduk, jumlah penduduk dan karakteristik desa, d) Sistem kepercayaan dan kemasyarakatan yaitu: menganut Agama Hindu dengan filosofi Tri Hita Karana, dan e) Ketersedia infrastruktur antara lain: fasilitas dan pelayanan transportasi, fasilitas kesehatan, pura, air dan listrik yang cukup memadai untuk menunjang kebutuhan masyarakat dan pengunjung.

Permasalahan yang dihadapi Desa Temukus-Besakih dalam mewujudkan desa ini sebagai desa wisata dilihat dari kriteria desa wisata yaitu: a) jarak tempuh jauh dari Kota Denpasar, b) Besaran desa antara lain: lahan belum tertata dengan baik, c) Ketersediaan infrastruktur antara lain: masalah persampahan, sistem pengolahan air limbah yang tidak optimal, jalan desa rusak, kondisi eksisting konstruksi drainase buruk, tempat parkir kurang tertata dengan baik, saluran irigasi tidak mengairi perkebunan secara maksimal dan terdapat beberapa fasilitas pelayanan publik dengan kondisi kurang terawat. Konsep dasar pengembangan Desa Temukus-Besakih sebagai desa wisata adalah "Desa Wisata Berkelanjutan". Konsep pengembangan dari konsep dasar tersebut terdiri dari rencana tata ruang. Rencana tata ruang terdiri dari zona lingkungan, zona sosial budaya, dan zona ekonomi.

\section{DAFTAR PUSTAKA}

Badan Pusat Statistik Kabupaten Karangasem. (2018). Retrieved March 28, 2019, from https://karangasemkab.bps.go.id/pressrelease/2018/10/26/160/kedatangan-wisatawan-mancanegara-wisman--ke-bali-pada-bulan-juni-2018-naik-3-03-persen-.htm

Badan Pusat Statistik Provinsi Bali. (2017). Retrieved March 31, 2019, from https://bali.bps.go.id/dynamictable/2018/02/02/213/pendapatan-asli-daerah-kabupaten-kota-se-bali2000-2016.html

BALIPOST. (2017). Potensi Tinggi, Market Bunga Gumitir Capai 200 Milyar Setahun | BALIPOST.com. Retrieved March 30, 2019, from http://www.balipost.com/news/2017/06/01/10266/PotensiTinggi,Market-Bunga-Gumitir...html 
Besakih - Google Maps. (2018). Retrieved April 6, 2018, from https://www.google.com/maps/place/Besakih,+Rendang,+Kabupaten+Karangasem,+Bali/@$8.35759,115.458306,12 \mathrm{z} / \mathrm{data}=! 4 \mathrm{~m} 5 ! 3 \mathrm{~m} 4 ! 1 \mathrm{~s} 0 \times 2 \mathrm{dd} 21 \mathrm{cdbadf} 6 \mathrm{~b} 35 \mathrm{~b}: 0 \times 5030 \mathrm{bfbca} 8315 \mathrm{f0} ! 8 \mathrm{~m} 2 ! 3 \mathrm{~d}-$ $8.3749056 ! 4 \mathrm{~d} 115.4510613 ? \mathrm{hl}=\mathrm{id}-\mathrm{ID}$

Desa Besakih. (2017). Retrieved March 29, 2019, from http://besakih.desa.id/?i=1

Dowling, R. (2003). Ecotourism in Thailand. Annals of Tourism Research, 23(2), $267-282$. https://doi.org/10.1016/s0160-7383(96)90075-4

Fenty, D. (2017). Ladang Bunga Marigold Bali | Indonesia Travel Agent \&amp; Bali Travel Agent | Indonesia Travel Agent \&amp; Bali Travel Agent. Retrieved March 29, 2019, from https://indoasiatourtravel.com/id/ladang-bunga-marigold-bali/

Garcia-Ramon, M. D., Canoves, G., \& Valdovinos, N. (1995). Farm tourism, gender and the environment in Spain. Annals of Tourism Research, 22(2), 267-282. https://doi.org/10.1016/0160-7383(94)00096-4

Iakovidou, O., \& Turner, C. (1995). The female gender in Greek agrotourism. Annals of Tourism Research, 22(2), 481-484. https://doi.org/10.1016/0160-7383(94)00099-9

Istri, S., \& Permata, S. (2016). PENGARUH KUNJUNGAN WISATAWAN, LAMA TINGGAL, TINGKAT KABUPATEN KARANGASEM. E-Jurnal Ekonomi Pembangunan Universitas Udayana, 7(6), 1282-1310.

Leu, W. (1992). The Swiss Experience, Universal Tourism Enriching or Degrading Culture. Yogyakarta: Gadjah Mada University Press.

METROBALI. (2013). Inilah Program Aksi Bali Mandara Jilid II I metrobali.com. Retrieved March 30, 2019, from http://metrobali.com/inilah-program-aksi-bali-mandara-jilid-ii/

Naisbitt, J. (1995). Global Paradox. Jakarta: Binapura Aksara.

Oppermann, M. (1996). Rural tourism in Southern Germany. Annals of Tourism Research, 23(1), 86-102. https://doi.org/10.1016/0160-7383(95)00021-6

Prasiasa, P. D. O. (2017). Strategi pengembangan dan pemberdayaan masyarakat desa wisata timbrah kecamatan karangasem kabupaten karangasem. Prosiding Seminar Nasional Hasil Penelitian-Denpasar, 103126.

Putra, I. S., Wayan, N. I., Utam, F., Agung, A., \& Sugianthara, G. (2017). Perencanaan Lansekap Desa Pertima sebagai Desa Wisata Berkelanjutan di Kecamatan Karangasem Kabupaten Karangasem. EJurnal Arsitektur Lansekap, 3(2), 147-157.

Rangkuti, F. (2017). Analisis SWOT-Teknik Membedah Kasus Bisnis. Jakarta: PT Gramedia Pustaka Utama.

Subrata, I. N., \& Nyoman Mastiani Nadra. (2006). Dampak ekonomi, sosial- budaya, dan lingkungan pengembangan desa wisata di jatiluwih-tabanan. Manajemen Pariwisata, 7(6), 46-64. 